\title{
Effect of captopril on the oxidative damage caused by pentylenetetrazole in the SHSY-5Y human neuroblastoma cell line
}

\section{Kaptoprillin SHSY=5Y insan nöroblastom hücre hattında pentilentetrazolün neden olduğu oksidatif hasar üzerindeki etkisi}

\author{
Murat Doğan ${ }^{1,3}$, Mustafa Karademir²
}

${ }^{1}$ Department of Pharmaceutical Biotechnology, Faculty of Pharmacy, Sivas Cumhuriyet University, Sivas, Turkey.
${ }^{2}$ Department of Neurosurgery, Faculty of Medicine, Sivas Cumhuriyet University, Sivas, Turkey.

Sivas Cumhuriyet University, School of Medicine, CUTFAM Research Center, Sivas, Turkey

Corresponding author: Murat Doğan, Department of Pharmaceutical Biotechnology, Faculty of Pharmacy, Sivas Cumhuriyet University, Sivas, Turkey.

E-mail: mdogan@cumhuriyet.edu.tr

Received/Accepted: November 24, 2020 /December 17,2020

Conflict of interest: There is not a conflict of interest.

\section{SUMMARY}

Objective: Epilepsy is a crucial brain disorder that seizures could cause a neuronal loss in the hippocampus. Oxidative stress has an important role in the pathology of this way. The aim of this study was to investigate the neuroprotective effect of captopril, on pentylenetetrazole (PTZ) induced epileptic seizures in SH-SY5Y cell line.

Method: In this XTT cell viability assay, captopril was performed in vitro SH-SY5Y cell culture to evaluate PTZ-induced neurotoxicity. Tissue TOS concentrations at the cell supernatants were quantified with the automated assay method. Hydrogen peroxide was used for the calibration of the assay.

Results: When XTT cell viability results were evaluated, captopril did not affect neuronal viability in SH-SY5Y cell line. Moreover, captopril did not have significant effect on TOS levels $(* * * \mathrm{P}>0.001)$

Conclusions: Results showed that, captopril did not have neuroprotective properties in SH-SY5Y cell line after PTZ-induced neurotoxicity.

Keywords: Neurotoxicity, captopril, PTZ.
(iD) Murat Doğan
(D) Mustafa Karademir

ORCID IDs of the authors: M.D. 0000-0003-2794-0177 M.K. 0000-0002-0734-9040

\section{ÖZET}

Amaç: Epilepsi, nöbetlerin hipokampusta nöron kaybına neden olduğu önemli bir beyin hastalığıdır. Oksidatif stres bu yolun patolojisinde önemli bir role sahiptir. Bu çalışmanın amacı, kaptoprilin, SH-SY5Y hücre hattında pentilentetrazol (PTZ) ile indüklenen epileptik nöbetler üzerindeki sinir koruyucu etkisini araştırmaktır.

Yöntem: XTT hücre canlılı̆̆1 deneyinde PTZ' nin neden olduğu nörotoksisiteyi değerlendirmek için kaptopril in vitro SH-SY5Y hücre kültüründe uygulandı. Hücre süpernatanlarındaki doku TOS konsantrasyonları otomatik test yöntemi ile ölçüldü. Analizin kalibrasyonu için hidrojen peroksit kullanıldı.

Bulgular: XTT hücre canlılığ1 sonuçları değerlendirildiğinde, kaptopril, SH-SY5Y hücre hattında nöronal canlılığ1 etkilemedi. Ayrıca, kaptoprilin TOS seviyeleri üzerinde de önemli bir etkisi olmamıştır (P>0. 001).

Sonuç: Sonuçlar, kaptoprilin, PTZ ile indüklenen SH-SY5Y hücre hattı nörotoksisitesinde sinir koruyucu etkiye sahip olmadığını gösterdi.

Anahtar sözcükler: Nörotoksisite, kaptopril, PTZ. 


\section{INTRODUCTION}

Epilepsy is defined as a central nervous system disorder characterized by repetitive seizures that generally occur due to a genetic predisposition or chronic pathological situation ${ }^{1,2}$. Assessment the role of oxidative stress in the pathophysiology of seizures is curicial to describe suitable therapeutic strategies. Components with antioxidant and neuroprotective function may perform positive effects when associated with antiepileptic properties. The frequent event of epileptic seizures considerably decreases the memory and learning capacity in patients with epilepsy ${ }^{3}$. It has been shown that pentylenetetrazole (PTZ)-induced seizures can cause memory impairment in rodents ${ }^{4}$. The hippocampus and cortex are both effective on memory and learning. Epileptic seizures lead to neuronal death via aggravating calcium influx into cells. Thus, the brain neuro-degenerates, particularly in the hippocampus, and changes the function of variable synapses that store information, which may be a statement of the observed learning disorder following seizure ${ }^{5,6}$. Experimental epilepsy models have been performed to explain the basic mechanisms include in epileptic seizures. PTZ is a chemical agent used to create experimental seizures which is a selective antagonist of the GABA-A receptor. PTZ causes adverse effects on the neuronal membrane, affects calcium and potassium channels, releases intracellular calcium ion reserves, and decreases the neurotransmitter-induced chloride conductivity. This model is clinically considered as an answer to temporal lobe epilepsy and complex partial epilepsy ${ }^{7,8}$. Captopril is one of the most commonly prescribed antihypertensive drugs that inhibits Angiotensin II (Ang II) converting enzyme (ACE). Captopril is commonly used for secondary prevention of cardiovascular events in patients with diabetes. It can selectively lower the Ang II, endothelin, and oxidative stress, which may have a potential role in its blood pressure-lowering effect ${ }^{5,9}$. It can pass the blood-brain barrier readily. Current literature show that decreased angiotensin II activity caused by ACE inhibitors can be associated with antidepressant and anxiolytic effects ${ }^{10,11}$.

The objective of the present study was to examine the neuroprotective effects of the ACE inhibitor captopril in SHSY-5Y cell lines.

\section{MATERIAL AND METHODS}

\section{In vitro studies}

\section{Cell culture}

SHSY-5Y (CRL-2266) cell lines were obtained from American Type Culture Collection and cultured in DMEM (Thermo Fisher Scientific, Altrincham, UK) containing $10 \%$ Fetal Bovine Serum (FBS) (Sigma-Aldrich Co., St Louis, MO, USA), $1 \%$ penicillin/streptomycin (Sigma Aldrich Co., St Louis, MO, USA), and 1\% L-glutamine (Sigma-Aldrich Co., St Louis, MO, USA). The cells were maintained in an incubator $\left(\right.$ at $37^{\circ} \mathrm{C}$ and $5 \% \mathrm{CO}_{2}$ humidified atmosphere). Captopril and pentylenetetrazole (PTZ) (Sigma-Aldrich Co., St Louis, MO, USA) were dissolved in DMEM and stock solutions were prepared before treatment.

\section{Cell viability assay}

Cell viability was evaluated using the XTT assay (Roche Diagnostic, MA, USA). Initially, SHSY$5 \mathrm{Y}$ cells were seeded in 96-well plates at a density of $1 \times 10^{4}$ cells in $100-\mu \mathrm{L}$ DMEM per well and incubated overnight before treatment. The following day, four-cell groups were prepared to assess the neuroprotective effect of captopril. The control group did not perform any treatment. Cells in the PTZ group were treated with $30 \mathrm{mM}$ PTZ for $24 \mathrm{~h}$. Cells in the captopril group were treated with various concentrations $(12.5,25,50,100$, and 200 $\mu \mathrm{M})$ of captopril for $24 \mathrm{~h}$. Cells in the PTZ+captopril group were treated with various concentrations $(12.5,25,50,100$, and $200 \mu \mathrm{M})$ of captopril for $1 \mathrm{~h}$ and then implemented to $30 \mathrm{mM}$ PTZ for $24 \mathrm{~h}$. After incubation, the medium was removed and wells were washed with phosphatebuffered saline (PBS). Then, $100 \mu \mathrm{L}$ DMEM without phenol red, and $50 \mu \mathrm{L}$ XTT labeling solution was added to all the wells, and then the plates were maintained at $37^{\circ} \mathrm{C}$ for $4 \mathrm{~h}$. The absorbance of samples was detected using an ELISA micro-plate reader (Thermo Fisher Scientific, Altrincham, UK) at $450 \mathrm{~nm}$. All the experiments were performed three times and the cell viability was measured as viable cell percentages compared to the control group (untreated cells).

\section{Preparation of cell homogenates}

The cells were collected in sterile tubes and were centrifuged at $2000 \mathrm{rpm}$ for $10 \mathrm{~min}$. Then, the supernatants were removed and the components of the cells were suspended using PBS ( $\mathrm{pH}$ 7.4) to dilute cell suspension of the cell concentration (approximately $1 \mathrm{million} / \mathrm{mL}$ ). The cells were damaged through repeated freeze-thaw cycles to 
let out the internal components of the cells and were centrifuged at $4000 \mathrm{rpm}$ for $10 \mathrm{~min}$ at a temperature of $4{ }^{\circ} \mathrm{C}$. Then, the supernatants were collected for biochemical analysis of total oxidant status (TOS) by using TOS commercial kit (Real Assay Kit Diagnostics, Antep, Turkey). The Bradford protein assay kit (Merck Millipore, Darmstadt, Germany) was used to determine the total protein levels in the samples.

\section{Measurement of TOS}

Tissue TOS concentrations at the cell supernatants were quantified with the automated assay method of Erel ${ }^{2}$. Because ferrous ions are oxidized into ferric ions when sufficient quantities of oxidants are available in the medium, the method allows for quantifying TOS levels by measuring tissue levels of ferric ions with the utilize of xylenol orange. Hydrogen peroxide was used for the calibration of the assay ${ }^{3}$. The results of the assay were expressed in micromolar hydrogen peroxide equivalents per milligram tissue protein $\left(\mu \mathrm{mol} \quad \mathrm{H}_{2} \mathrm{O}_{2} \mathrm{Eq} / \mathrm{mg}\right.$ protein).

\section{Statistical analysis}

The results were expressed as a mean \pm standard deviation of mean (SEM). The data analyses were evaluated using a one-way analysis of variance (ANOVA). Newman Tukey test was utilized to determine the differences between the experimental groups.

\section{RESULTS}

Effects of captopril on cell viability after PTZ-induced neurotoxicity in SH-SY5Y cells

An XTT cell viability assay was performed to assess the neuroprotective effects of captopril on PTZ-induced SH-SY5Y cell toxicity. In the previous studies, the IC50 value of PTZ in the SHSY5Y cell was found as $30 \mathrm{mM}$ and this value was used in this study ${ }^{8}$. As presented in Fig. 1, constant concentration of PTZ $(30 \mathrm{mM})$ treatment considerably reduced cell viability compared to the control $(\mathrm{P}<0.001)$. According to the results, it can be said that PTZ has a neurotoxic effect in SHSY5Y cell line. However, when applied together, captopril did not exhibit neuroprotective effects at $12.5-200 \mathrm{mg} / \mathrm{mL}$ concentrations $(* * * \mathrm{P}>0.001)$. In addition, treatment of captopril at the dose of 12.5 $\mathrm{mg} / \mathrm{mL}$ showed the least neurotoxicity compared to other applied doses of captopril in SH-SY5Y cells (Figure 1). There were not significant differences to the cell viability of PTZ-induced SH-SY5Y cells when the treatment of captopril at different doses. It was expected to be highest SH-SY5Y cell viability at the treatment of captopril with 200 $\mathrm{mg} / \mathrm{ml}$ dose. However, at this dose, SH-SY5Y cells showed the least cell viability. In addition, there was no significant difference in viability of control group and SH-SY5Y cells treated with different concentrations of captopril in cells without the treatment of PTZ.

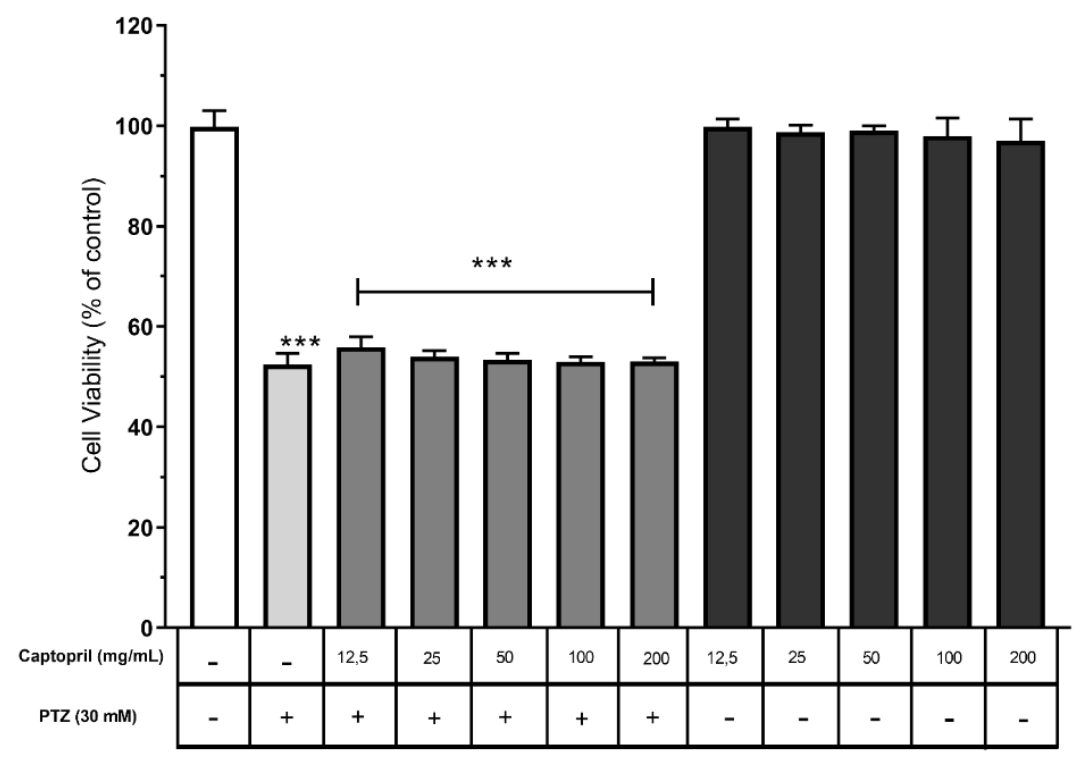

Figure 1: Effects of captopril on cell viability after PTZ induced neurotoxicity in SH-SY5Y cells. Values are presented as mean $\pm \mathrm{SD}(* * * \mathrm{P}>0.001)$. 


\section{Assessment of captopril on TOS levels after PTZ-induced neurotoxicity in SH-SY5Y cells}

The TOS levels in SH-SY5Y cells were measured using commercial kits. TOS levels in SH-SY5Y cells were significantly increased in only PTZ- treated cells compared to the control $(\mathrm{P}<0.001$; Figure 2). Captopril alone had no notable effect on the TOS level in SH-SY5Y cells $(* * * \mathrm{P}>0.001)$. Captopril treatment at a dose of $100 \mathrm{mg} / \mathrm{mL}$ did not crucial effect on TOS levels in SH-SY5Y cells after PTZ-induced neurotoxicity (***P>0.001).

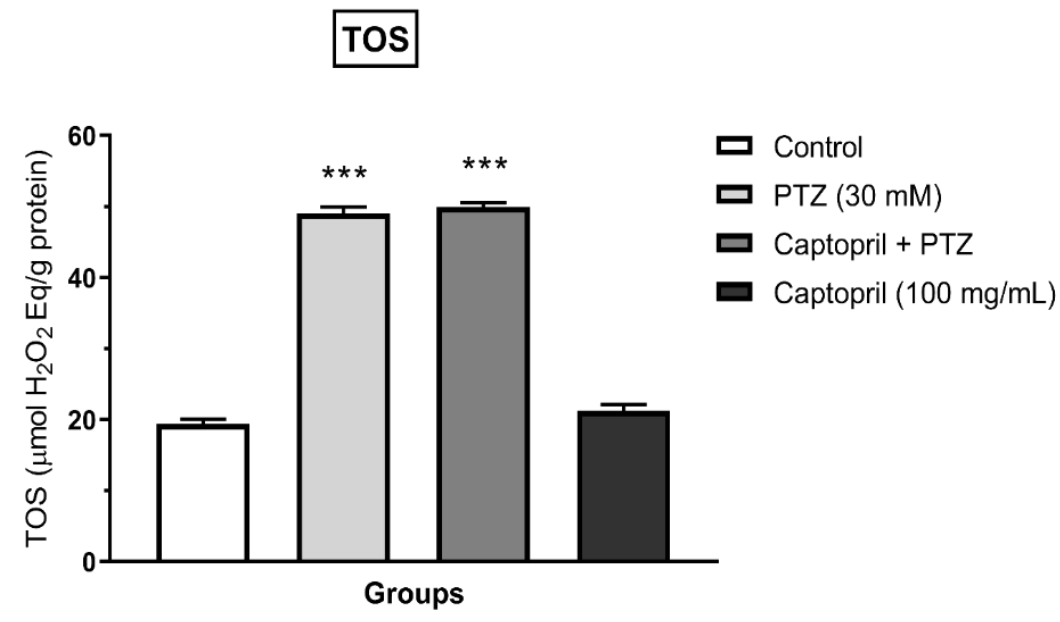

Figure 2: Effects of captopril on TOS levels after PTZ-induced neurotoxicity in SH-SY5Y cells. Values are presented as mean $\pm \mathrm{SD}(* * * \mathrm{P}>0.001)$.

\section{DISCUSSION}

Captopril is commonly utilized ACE inhibitory, selectively and potently inhibiting ACE. Several recent studies have shown that oxidative stress and inflammation consisted of crucial part in the pathogenesis of epileptogenesis. It has been reported that captopril reduces oxidative stress and inflammation levels in tissues and they significantly increased the epileptic threshold ${ }^{12}$. Several experimental studies show that captopril has neuroprotective and antioxidant effects under different conditions in the rodent brain. A study reported that captopril improved the memory function by reducing oxidative stress in the hippocampus ${ }^{13}$. Our present study results showed that there were not significant differences to the cell viability of PTZ-induced SH-SY5Y cells when the treatment of captopril. Captopril treatment at a determined dose did not significant effect on TOS levels in SH-SY5Y cells after PTZ-induced neurotoxicity.

\section{Acknowledgement}

The authors would like to thank the Sivas Cumhuriyet University, School of Medicine, CUTFAM Research Center, Sivas, Turkey, for providing the necessary facilities to conduct this study.

\section{Disclosure Statement}

The authors have no conflict of interest to disclose.

\section{REFERENCES}

1. Karabulut S, Bayramov R, Korkmaz Bayramov K, Filiz AK, Taskiran AS, Ozdemir E. Effect of the allopregnanolone and allotetrahydrodeoxycortico steron on spike-wave discharges in the EEG of absence epilepsy rat models, General Physiology and Biophysics, 2018; 37: 205-211.

2. Erel O, A novel automated method to measure total antioxidant response against potent free 
radical reactions. Clin Biochem, 2004; 37: 112119.

3. Taskıran AŞ, Ergül M, Güneş H, Ozturk A, Sahin B, Ozdemır E. The Effects of Proton Pump Inhibitors (Pantoprazole) on Pentylenetetrazole-Induced Epileptic Seizures in Rats and Neurotoxicity in the SH-SY5Y Human Neuroblastoma Cell Line. Cellular and Molecular Neuroblology, 2020.

4. Lamberty $\mathrm{Y}$, Klitgaard $\mathrm{H}$. Consequences of pentylenetetrazole kindling on spatial memory and emotional responding in the rat. Epilepsy Behav, 2000; 1: 256-261.

5. Bolterman RJ, Manriquez MC, Ruiz MCO, Juncos LA, Romero JC. Effects of captopril on the renin angiotensin system, oxidative stress, and endothelin in normal and hypertensive rats. Hypertension, 2005; 46: 943-947.

6. Ramos SF, Mendonça BP, Lefa DD et al. Effects of neuropeptide $S$ on seizures and oxidative damage induced by pentylenetetrazole in mice. Pharmacol Biochem Behav, 2012; 103: 197-203.

7. Potschka H. Animal models of drug-resistant epilepsy. Epileptic Disorder, 2012; 14: 226-234.

8. Kalantaripour T, Esmaeili-Mahani S, Sheibani $\mathrm{V}$ et al (2017) Apelin-13 protects rat primary cortical glia-neuron co-culture against pentylenetetrazole-induced toxicity. Biomed Pharmacother, 2017; 87: 661-668.

9. Tastemur Y, Gumus E, Ergul M, Ulu M, Akkaya R, Ozturk A, Taskıran AȘ. Positive effects of angiotensin-converting enzyme (ACE) inhibitor, captopril, on pentylenetetrazole-induced epileptic seizures in mice. Trop J Pharm Res, 2020; 19: 637643.

10. Whitlock JR., Learning induces long-term potentiation in the hippocampus. Science, 2006; 313: 1093-1097.

11. Curia G, Lucchi C, Vinet J, Gualtieri F, Marinelli C, Torsello A, Costantino L, Biagini G. Pathophysiogenesis of Mesial Temporal Lobe Epilepsy: Is Prevention of Damage Antiepileptogenic? Curr Med Chem, 2014; 21(6): 663-688.

12. Abraham J, Fox PD, Condello C, Bartolini A, Koh S. Minocycline attenuates microglia activation and blocks the long-term epileptogenic effects of early-life seizures. Neurobiol Dis 2012;46(2):42530.

13. Bild W, Hritcu L, Stefanescu C, Ciobica A. Inhibition of central angiotensin II enhances memory function and reduces oxidative stress status in rat hippocampus. Prog Neuro-Psy chopharmacology Biol Psychiatry 2013;(43):7988. 